Review

\title{
Are we killing them with kindness? Evaluation of sustainable marine wildlife tourism
}

\author{
Claudia Trave ${ }^{\text {a,b,d,* }}$, Juerg Brunnschweiler ${ }^{c}$, Marcus Sheaves ${ }^{\text {a,b,d }}$, Amy Diedrich ${ }^{\text {a,b,d }}$, Adam Barnett ${ }^{\text {a,d }}$ \\ ${ }^{a}$ College of Science and Engineering, James Cook University, Townsville, Qld 4811, Australia \\ b TropWATER (Centre for Tropical Water \& Aquatic Ecosystem Research), Townsville, Australia \\ ' Independent Researcher, Gladbachstrasse 60, 8044 Zurich, Switzerland \\ d James Cook University, Australia
}

\section{A R T I C L E I N F O}

\section{Article history:}

Received 5 May 2016

Received in revised form 5 February 2017

Accepted 8 February 2017

Available online 24 February 2017

\section{Keywords:}

Marine wildlife tourism

Ecotourism

Sustainability

Ecological impact

Management

Regulations

\begin{abstract}
A B S T R A C T
The increasing popularity of marine wildlife tourism (MWT) worldwide calls for assessment of its conservation outcomes and the development of appropriate management frameworks to ensure the conservation of the species and habitats involved as well as the long-term sustainability of this industry. While many studies have examined the positive and/or negative implications of particular forms of MWT, few have attempted to identify factors of concern shared across different types of marine tourism, or examine their implications for sustainability in a broader perspective. We reviewed the existing literature to highlight common impacts on animal behaviour, health and ecology, and to identify successful cases based on minimal negative affects and/or lack of chronic/ irreversible impacts on target species or habitats. To ensure the achievement of both economic and ecologic objectives, the following steps should be integrated in MWT management: 1) Increase of research on the biology and ecology of target species/habitat and application of relevant information for the development of suitable policies, frameworks and management strategies; 2) Structured enforcement of existing policies and enhancement of ecological awareness of visitors through active education; 3) Application of an adaptive management framework to continuously improve the codes of conduct employed; 4) Involvement of different stakeholders and local communities in the development and improvement of the MWT activity. Combining these strategies with the extrapolation of frameworks and policies from cases where adverse ecological impacts have been addressed and successfully resolved can further contribute in ensuring the long-term health and conservation of the species/ habitats involved in MWT activities.
\end{abstract}

(c) 2017 Elsevier Ltd. All rights reserved.

\section{Contents}

1. Introduction $\ldots, \ldots, \cdot, 212$

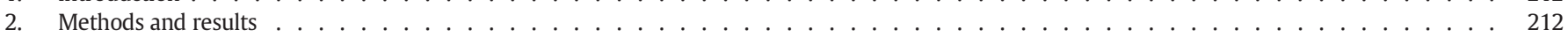

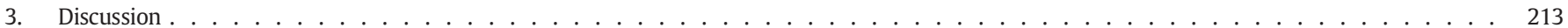

3.1. Assessing marine wildlife tourism . . . . . . . . . . . . . . . . . . . . . . . . . . . . . . . . . . . 213

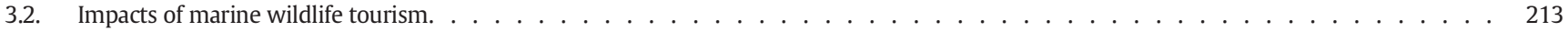

3.2.1. Human presence. . . . . . . . . . . . . . . . . . . . . . . . . . . . . . 213

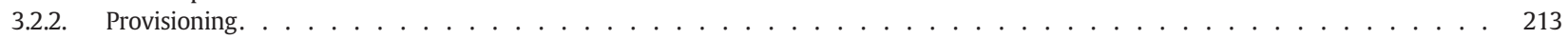

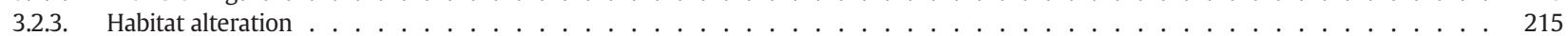

3.3. Sustainability of marine wildlife tourism . . . . . . . . . . . . . . . . . . . . . . . . 215

3.3.1. EXAMPLE 1 - grey nurse shark (Eastern Australia) . . . . . . . . . . . . . . . . . . . . . . . . . 215

3.3.2. EXAMPLE 2 - minke whale (Northern Australia) . . . . . . . . . . . . . . . . . . . . . . . . . . 215

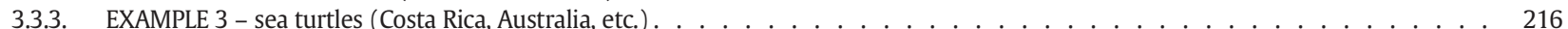

3.4. Recurring issues in marine wildlife tourism . . . . . . . . . . . . . . . . . . . . . . . . . . . 216

3.4.1. Lack of background information and baseline data . . . . . . . . . . . . . . . . . . . . . . . . . . . . . . 216

3.4.2. Lack of physiological data. . . . . . . . . . . . . . . . . . . . . . . . . . . . . . . . . . . . . . . . . . . . . . . . . . . . .

\footnotetext{
* Corresponding author at: ATSIP Building 145, James Cook University, Townsville, Qld 4811, Australia.

E-mail address: claudia.trave1@jcu.edu.au (C. Trave).
} 
3.4.3. Poor management and frameworks . . . . . . . . . . . . . . . . . . . . . . . . 216

3.4.4. Lack of proper implementation and enforcement . . . . . . . . . . . . . . . . . . . . . . . . . 217

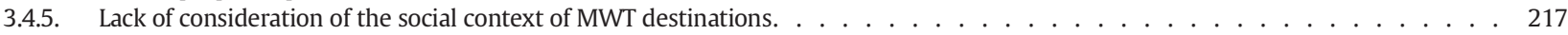

3.5. Strategies for effective management of marine wildlife tourism . . . . . . . . . . . . . . . . . . . . . . . . 217

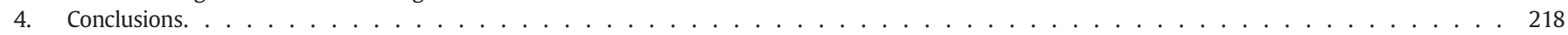

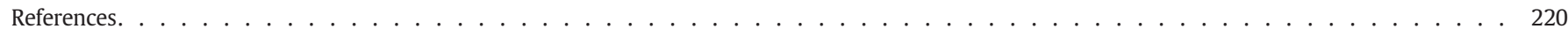

\section{Introduction}

Wildlife tourism, the practice of observing wild animals in their natural environment has been steadily increasing along with human population growth, with the number of participants estimated to be between 79 and 440 million (International Ecotourism Society, 2000; Moorhouse et al., 2015) and projected to double over the next 50 years (French et al., 2011). If conducted responsibly, wildlife tourism can provide substantial financial benefits to local communities (Ballantyne and Packer, 2013; Gallagher and Hammerschlag, 2011; O'Malley et al., 2013) while at the same time contributing to conservation efforts. The protection of the species and habitats involved in this practice (Troëng and Rankin, 2005; Wilson, 2003) and the conversion to a more environmentally-focused use of ecological resources (Ballantyne and Packer, 2013, Brunnschweiler, 2010, Landry and Taggart, 2010) are primary objectives of wildlife tourism. However, it is also imperative that wildlife tourism itself is managed efficiently to ensure negative impacts do not outweigh the positives gained. Environmental impacts range from changes in behaviour, health or ecology of specific species involved (e.g. Clarke et al., 2013; Haskell et al., 2015; Orams, 2002 ) to broader scale ecosystem changes, such as habitat alterations (e.g. Green and Higginbottom, 2001; Tisdell and Wilson, 2005a).

At present it is still unclear whether wildlife tourism is truly succeeding in achieving its conservation objectives, or if the direct and indirect effects on the environment counter its ecological benefits. Additionally, while the success of a tourism operation is evaluated for its 'ecological sustainability', a clear or commonly agreed on definition of this term has not yet been developed (Harding, 2006; Hardy et al., 2002; Swarbrooke, 1999). This leaves room for loose interpretations, misunderstandings and general lack of clarity in determining the conservation benefits of individual wildlife tourism operations and the industry as a whole. In the context of this paper we define an ecologically sustainable activity as one that does not result in chronic or irreversible detrimental changes. This includes long-term negative changes in behaviour, physiology, fitness and population dynamics of the organisms involved and alteration of the habitat structure or ecosystem functions. For example, despite the detection for different shark species of short-term behavioural changes linked to provisioning events, feeding operations do not appear to drive their long-term movements (Brunnschweiler and Barnett, 2013; Huveneers et al., 2013; Laroche et al., 2007; Meyer et al., 2009). This suggests a limited level of impact of this particular tourist activity on the animals involved, as no long-term or irreversible effects on their behaviour were observed.

To assess ecological sustainability of marine wildlife tourism in general, we reviewed the published scientific literature on marine wildlife tourism activities to (1) compare and contrast the environmental impacts and potential trends between the different forms of marine wildlife tourism (MWT; see Box 1 for definitions), (2) highlight key examples of sustainable MWT to derive successful management frameworks, (3) identify common hindrances to the achievement of ecologically sustainable MWT, and (4) discuss core elements and management strategies that can been employed at local or international level to maximize ecological benefits and minimize negative impacts of MWT practices.
Box 1

Terminology. Definitions of terms associated with wildlife tourism derived from the literature covered in this review.

Marine wildlife tourism (MWT) - A form of non-consumptive tourism that focuses on the observation of marine species and habitats, and in some cases even direct human-animal interaction.

Megafauna-watching - The practice of observing large wild marine animals from the shore or using operator manned vessels, without directly interacting with them.

Swim-with megafauna - The practice of observing large wild marine animals in the water through regulated snorkelling/SCUBAdiving activities.

Provisioning - The practice of using food to attract target marine species increasing the chances of observing them, or to promote a direct interaction between tourists and animals in a controlled situation by means of feeding.

Ecological sustainability - Ensuring that the tourist practices performed don't have chronic or irreversible ecological changes when compared to the existing baseline information collected through scientific research or local historical records.

\section{Methods and results}

Search engines Google Scholar, Web of Science and Science Direct were used to obtain peer reviewed publications related to marine wildlife tourism. A first selection was made with the use of the following keywords and combinations of these words: marine wildlife tourism, marine ecotourism, sustainable tourism, whale-watching, SCUBA diving, shark diving, provisioning, sea turtle tourism, pinniped-watching, marine bird-watching and tourism management. This preliminary search led to over 90.000 results, the majority of which however resulted to be not relevant to this review as focusing on topics not related to MWT ecological impacts and management. Grey literature e.g. unpublished theses, conference proceedings and non-peer reviewed publications were also excluded. A further selection was then carried out by sorting the publications obtained using the following criteria: the study should have as main focus MWT-related research, monitoring, management and/or sustainability. This led to a total of 396 publications with a wide geographical range, extending from Arctic to the tropics. Each study was then sorted in one or more categories based on the different types of MWT discussed, focusing on those most commonly studied in the literature (see Box 1).

Whale-watching was the most investigated topic, with 121 studies (30.5\% of the 396 publications selected) focusing on evaluating direct and indirect impacts of whale-watching practices on different species and analysing/proposing management strategies. 63 publications (15.9\%) addressed the topic of SCUBA diving (or 'reef' diving) in relation to environmental impacts, compliance to policies and current management practices or codes of conduct. 56 studies (14.1\%) focused on elasmobranch tourism (mainly shark species), 30 (7.6\%) on sea turtles. And 19 studies each (4.8\%) for both pinniped-and shorebird-watching.

Management frameworks, achievement of set conservation goals and socio-economic implications were addressed in almost all papers examined, either by merely acknowledging their importance for the 
improvement of MWT or conducting thorough analyses of current status from a local case-specific to a global scale. Despite the fact that the majority of the publications examined focused on or even just mentioned the concepts of 'ecologically sustainable (tourism)' and 'sustainability', no comprehensive definition of the terms was presented, and only few papers acknowledged this fact (1.7\%) or provided a contextual definition (3.6\%).

\section{Discussion}

Through the review of the papers selected we identified information relevant to address the focal topics highlighted in the introduction: assessing the current status and sustainability of MWT around the globe and provide insight on different perspectives and approaches to overcome its conservation and management issues.

The information is presented in the sections below following these major themes:

1) Assessment of marine wildlife tourism: underlying approaches, perspectives and obstacles.

2) Observed impacts of MWT on the different species/habitat involved.

3) Recorded 'sustainable' cases of MWT and shared characteristics.

4) Recurring issues hindering sustainable MWT.

5) Proposed strategies for effective management of MWT and achievement of ecological conservation objectives.

Additional data files that contain information directly supportive of the topics presented in this work are provided as Appendices.

\subsection{Assessing marine wildlife tourism}

Wildlife tourism (WT) impacts the environment, even if marginally, as the mere presence of humans is sufficient to affect a habitat's composition or a species' behaviour/physiology (e.g. Burger et al., 1995; Fowler, 1999). Thus, the issue is to assess if the level of impact is acceptable for the tourism operation to be considered ecologically sustainable. While acknowledging that a consistent definition of this term is currently not available, a series of criteria that are commonly presented in the literature as indicators of success or as essential elements associated to an economically and ecologically sustainable practice can be employed to evaluate each MWT practice on a case-by-case basis, as well as generically. These criteria include: 1) increased awareness and/or conservation effort relating to the marine species involved (Orams and Hill, 1998; Tisdell and Wilson, 2005a; Zeppel and Muloin, 2007), 2) limited/no negative effects on their behaviour, ecology and physiology (Birtles and Mangott, 2013; Smith et al., 2014), 3) an organised and adaptable management of the marine resources that prioritises the welfare of the habitat/species involved (Higham et al., 2008; Landry and Taggart, 2010), and 4) direct and active involvement of local communities and relevant authorities in the management of the MWT activity (Brunnschweiler, 2010; Scheyvens, 1999). By assessing whether these criteria are met when evaluating a MWT practice, it is possible to highlight key elements in research and management that require to be addressed and/or improved to ensure the achievement of the conservation goals set for this practice.

Evaluating whether a MWT practice meets these criteria is however just a first step toward the improvement of its ecological sustainability. The understanding of the different ecological impacts caused by MWT on the environment (at local and international scales) and their specific cause is fundamental for the development of suitable strategies for the improvement of MWT policies focusing on species and habitat conservation.

\subsection{Impacts of marine wildlife tourism}

As shown in the extensive records and literature present, the most popular and widespread forms of marine wildlife tourism are cetacean-watching, shark-watching, provisioning, SCUBA diving/ snorkelling, marine bird-watching and observing pinniped and sea turtles on land and in water. These tourism practices have been considered socio-economically successful and ecologically sustainable in the shortterm (Burgin and Hardiman, 2015) based on loose definitions and contextual goals. However, there is considerable controversy now surrounding many of these ventures because of their impacts on habitat and/or species involved (Silva, 2015). Although the changes observed are often classified as case-specific or temporary (Apps et al., 2015; Barker et al., 2011a), the continuous presence and cumulative effect of such negative impacts is likely to have long-term consequences (Barker et al., 2011b) such as decrease in health or reproductive fitness (e.g. Burger et al., 1995; Orams, 2002), population alterations (e.g. Brunnschweiler et al., 2014; Clarke et al., 2013) and habitat shifts (e.g. Bravo et al., 2015; Hawkins et al., 1999).

Despite the overall lack of long-term studies investigating the extended ecological impact of MWT, the existing evidence on the topic has highlighted the alteration of the behaviour, ecology and physiology of several target species (Table 1a-b; Appendix 1).

\subsubsection{Human presence}

Most of the impacts observed are involuntary and/or secondary consequences of the presence and conduct of tourists and operators. High boat/human density and unpredictable maneuvering have been reported as immediate causes of stress and alteration of behaviour, population dynamics and distribution of the many species involved in MWT activities. The review of the literature showed 14 elasmobranchs, over 40 species of teleosts, 5 cetaceans, 8 pinniped species, over 10 species of shorebirds, 3 marine reptiles, and over 20 species of anthozoa and benthic organisms being affected by the presence and behaviour of humans during MWT activities (Table 1a; Appendix 1). The presence of humans in proximity to wild animals often causes disruption of diel activities such as feeding (Christiansen et al., 2013), nesting (Anderson and Keith, 1980), nursing of youngs (Andersen et al., 2012; Kovacs and Innes, 1990), communication (Jensen et al., 2008), and leads to an increase in avoidance behaviours (Andersen et al., 2012; Blane and Jaakson, 1994; Haskell et al., 2015), alert signals (Cubero-Pardo et al., 2011), and threatening/aggressive displays (Stafford-Bell et al., 2012). In some cases, lack of coordination between vessels or reckless driving has led to accidental injury of the target animal (Araujo et al., 2014; Bryant, 1994; Denkinger et al., 2013). There is also concern that overcrowding of divers/snorkelers and high number of boats at popular sites could even lead to the abandonment of that location (Barker et al., 2011b; Burger et al., 1995), a significant issue when considering species with feeding/breeding site fidelity, such as cetaceans, pinnipeds, sea turtles and shorebirds. The presence of humans can also affect reproductive rates, breeding success and caring for young (Burger and Gochfeld, 1993; French et al., 2011).

The handling and riding of marine animals still occurs (e.g. sharks in the Bahamas), as reported both by the literature (e.g. Gallagher et al., 2015; Tisdell and Wilson, 2005a) and social media. Some operators do so in front of customers to increase the excitement in the experience, but there is little information on the effects that this may have on animal health. For example, sharks being handled and placed into tonic immobility (a trance-like state) may suffer from negative physiological/ biochemical effects and increased stress (Brooks et al., 2011; Davie et al., 1993; Gallagher et al., 2015). The practice of handling/touching marine fauna is however becoming rarer as many operators have worked on developing/applying appropriate management frameworks and ensuring the enforcement of regulations and codes of conduct aimed at the conservation of the local marine species and habitats (Barker and Roberts, 2004; Camp and Fraser, 2012; Fabinyi, 2008; Luna et al., 2009).

\subsubsection{Provisioning}

Marine tourism often involves provisioning wildlife (see Box 1 for definition) to concentrate animals such as elasmobranchs, teleosts and 
Table 1a

Summary of documented consequences on target organisms/habitats of human presence and activities linked to MWT practices around the world. (see Appendix 1 for details concerning the species involved, case studies and related publications).

\begin{tabular}{|c|c|c|}
\hline Activity/disturbance & Observed consequence & $\begin{array}{l}\text { Number of cases } \\
\text { recorded for each } \\
\text { group }\end{array}$ \\
\hline \multirow[t]{16}{*}{$\begin{array}{l}\text { Presence of humans } \\
\text { and/or excessive } \\
\text { proximity }\end{array}$} & $\begin{array}{l}\text { Disruption of activities or altered } \\
\text { behaviour }\end{array}$ & $\begin{array}{l}\text { Elasmobranchs: } \\
11 \\
\text { Teleosts: } 1 \\
\text { Cetaceans: } 6 \\
\text { Pinnipeds: } 10 \\
\text { Shorebirds: } 8\end{array}$ \\
\hline & $\begin{array}{l}\text { Disruption of communication } \\
\text { between individuals }\end{array}$ & Cetaceans: 2 \\
\hline & Vocalization changes & Pinnipeds: 1 \\
\hline & Alert signals & $\begin{array}{l}\text { Elasmobranchs: } 1 \\
\text { Pinnipeds: } 1 \\
\text { Marine reptiles: } 1\end{array}$ \\
\hline & Aggressive behaviour displays & Pinnipeds: 1 \\
\hline & Increased predation susceptibility & Elasmobranchs: 1 \\
\hline & Habituation & $\begin{array}{l}\text { Elasmobranchs: } 1 \\
\text { Cetaceans: } 1 \\
\text { Pinnipeds: } 1\end{array}$ \\
\hline & $\begin{array}{l}\text { Evasive behaviour or site } \\
\text { abandonment }\end{array}$ & $\begin{array}{l}\text { Elasmobranchs: } 7 \\
\text { Cetaceans: } 3 \\
\text { Pinnipeds: } 6 \\
\text { Marine reptiles: } 1 \\
\text { Shorebirds: } 6\end{array}$ \\
\hline & $\begin{array}{l}\text { Alteration of spatio-temporal } \\
\text { movements and patterns }\end{array}$ & $\begin{array}{l}\text { Elasmobranchs: } 3 \\
\text { Cetaceans: } 2\end{array}$ \\
\hline & $\begin{array}{l}\text { Change in species } \\
\text { composition/abundance }\end{array}$ & Cetaceans: 1 \\
\hline & $\begin{array}{l}\text { Changes in population } \\
\text { structure/dynamics }\end{array}$ & $\begin{array}{l}\text { Elasmobranchs: } 1 \\
\text { Teleosts: } 1 \\
\text { Pinnipeds: } 2\end{array}$ \\
\hline & Decrease in reproduction rate & Pinnipeds: 1 \\
\hline & $\begin{array}{l}\text { Alteration of nesting distribution } \\
\text { or abundance }\end{array}$ & Shorebirds: 7 \\
\hline & $\begin{array}{l}\text { Decrease in nesting success (loss } \\
\text { of egg and young; nest } \\
\text { abandonment; trampling) }\end{array}$ & Shorebirds: 5 \\
\hline & Alteration of pup/chick behaviour & $\begin{array}{l}\text { Pinnipeds: } 1 \\
\text { Shorebirds: } 3\end{array}$ \\
\hline & $\begin{array}{l}\text { Physiological stress (alteration of } \\
\text { corticosterone levels or other } \\
\text { stress indicators) }\end{array}$ & $\begin{array}{l}\text { Pinnipeds: } 1 \\
\text { Shorebirds: } 1\end{array}$ \\
\hline $\begin{array}{l}\text { High density of vessels } \\
\text { and/or uncoordinated } \\
\text { maneuvering }\end{array}$ & Physical injury to animals & $\begin{array}{l}\text { Elasmobranchs: } 5 \\
\text { Marine reptiles: } 1\end{array}$ \\
\hline \multirow[t]{3}{*}{$\begin{array}{l}\text { Divers' contact with } \\
\text { bottom/reef }\end{array}$} & $\begin{array}{l}\text { Physical damage of benthic } \\
\text { flora/fauna (breakage; abrasion; } \\
\text { sedimentation) }\end{array}$ & $\begin{array}{l}\text { Benthic } \\
\text { flora/fauna: } 19\end{array}$ \\
\hline & $\begin{array}{l}\text { Increased susceptibility to disease } \\
\text { or other stressors }\end{array}$ & Anthozoa: 2 \\
\hline & $\begin{array}{l}\text { Change in benthic structure, } \\
\text { species composition/dominance }\end{array}$ & $\begin{array}{l}\text { Benthic } \\
\text { flora/fauna: } 3\end{array}$ \\
\hline $\begin{array}{l}\text { Divers interaction with } \\
\text { fauna }\end{array}$ & Alteration of behaviour & Elasmobranchs: 5 \\
\hline \multirow[t]{2}{*}{ Photography } & Stress of target species & $\begin{array}{l}\text { Shorebirds: } 1 \\
\text { Anthozoa: } 1\end{array}$ \\
\hline & $\begin{array}{l}\text { Damage of the surrounding } \\
\text { habitat to access the target species }\end{array}$ & Anthozoa: 3 \\
\hline \multirow{3}{*}{$\begin{array}{l}\text { Inappropriate tourist' } \\
\text { behaviour }\end{array}$} & Alert signals & Pinnipeds: 1 \\
\hline & $\begin{array}{l}\text { Disruption of activities or altered } \\
\text { behaviour }\end{array}$ & Pinnipeds: 1 \\
\hline & Aggressive behaviour & Cetaceans: 1 \\
\hline Anchoring & $\begin{array}{l}\text { Physical damage to the benthic } \\
\text { habitat and reef }\end{array}$ & Anthozoa: 4 \\
\hline Pollution & Decreased habitat health & $\begin{array}{l}\text { Benthic } \\
\text { flora/fauna: } 4\end{array}$ \\
\hline
\end{tabular}

dolphins for reliable viewing by visitors. Of the 48 provisioning studies reviewed, 89.5\% have highlighted how these practices can affect behaviour, with changes that range from minor short-term disturbances to long-term modifications of activities and conditioning to feeding events, even causing dependency and habituation (Table 1b; Appendix 1). In some cases, constant human-animal interaction increases risk of injury for both tourists and animals (e.g. Cunningham-Smith et al., 2006; Holmes and Neil, 2012), and can also lead to inter-/intra-species competition (e.g. Brunnschweiler et al., 2014; Clarke et al., 2013) or aggression (e.g. Clua et al., 2010; Orams, 2002; Smith et al., 2008) (Table 1b; Appendix 1). For example, cases of restlessness and 'pushy' behaviour toward tourists caused by delay in food delivery or undesired physical contact can occur during the provisioning of wild dolphins (e.g. Holmes and Neil, 2012; Cunningham-Smith et al., 2006; Orams et al., 1996).

Aside from affecting the behaviour of the animals, provisioning also has the potential to negatively influence their health, particularly when inappropriate/artificial food is used (Newsome et al., 2004) (Table 1b; Appendix 1). Despite the ever growing popularity of MWT provisioning practices, there is only minimal information available on its effects on animal health (sometimes with contradictory results) and detailed long-term studies have yet to be carried out (Burgin and Hardiman, 2015; Gallagher et al., 2015). For example, elasmobranch tourism occurs in approximately 85 countries (Gallagher et al., 2015), yet the effects of tourism activities on animal behaviour and/or health have only been studied to some degree for 19 species ( 17 species in provisioning studies) in 18 locations (Table 1b). The literature clearly shows that tourism can affect elasmobranch behaviour (Table 1a-b; Appendix 1), but little is known about adverse effects on long-term health. Although some studies acknowledged possible health issues (e.g. Clua et al., 2010; Fitzpatrick et al., 2011; Barnett et al., 2016), evidence thus far would suggest that the Grand Cayman Island provisioning of southern stingrays Dasyatis americana is the only operation with a definitive negative effect on the health of the target species (Corcoran et al., 2013; Semeniuk et al., 2007; Semeniuk et al., 2009).

The nature of the provisioning site (temporary or permanent) may play a role in influencing the long-term health of animals as much as the intrinsic characteristics of each species (Araujo et al., 2014; Barnett et al., 2016; Laroche et al., 2007).

\section{Table 1b}

Summary of documented consequences on target organisms/habitats of provisioning and activities linked to MWT practices around the world. (See Appendix 1 for details concerning the species involved, case studies and related publications).

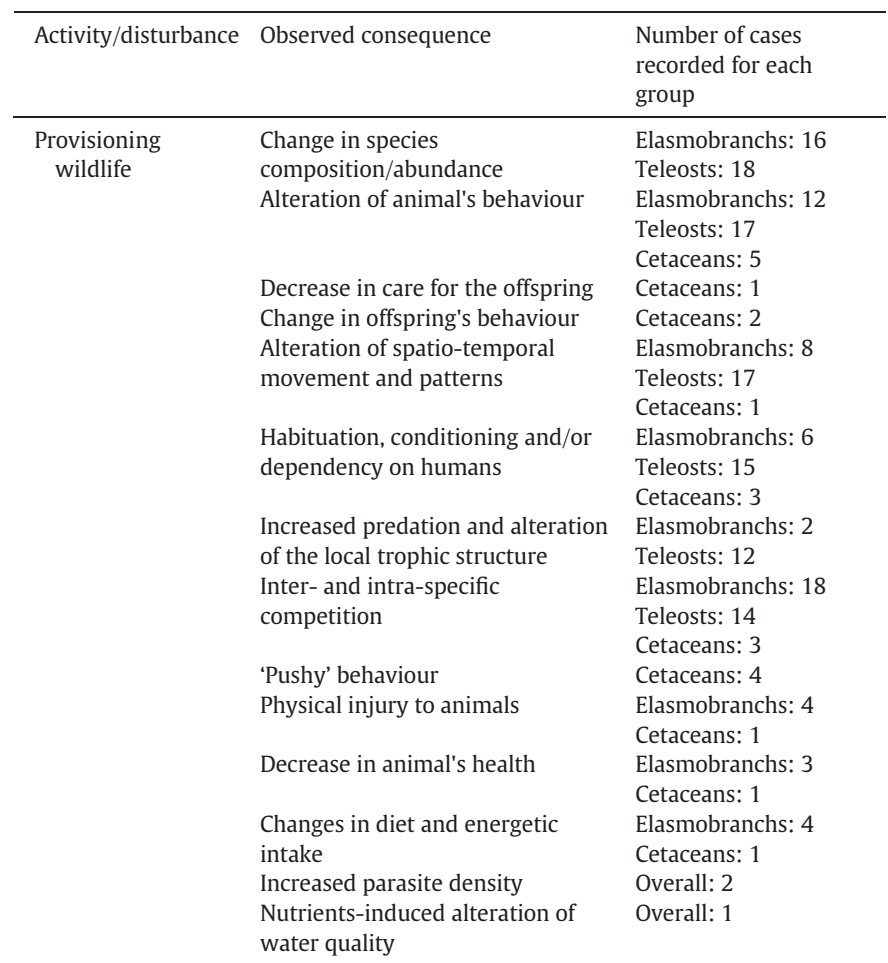


Provisioning can also directly and indirectly affect trophic dynamics, structure and health of local habitats by altering species composition and/or abundance, variations in the size structure and trophic structure of the marine community (Table $1 \mathrm{~b}$ ). For example, given that bottom feeding batoids are highly influential in structuring benthic communities (Hines et al., 1997), the increased residency resulting from tourism at stingray city in Grand Cayman Island suggests that predation $(>160$ stingrays) more than likely modifies and then regulates the structure of the benthic community at and around the feeding site (Corcoran et al., 2013).

\subsubsection{Habitat alteration}

Habitat degradation and physical damage are other consequences associated with the development of MWT, particularly with regard to SCUBA diving (Di Franco et al., 2009; Hasler and Ott, 2008) or vessel-dependent activities (Jameson et al., 1999; Saphier and Hoffmann, 2005). The behaviour of both operators and tourists is the major determining factor in the alteration of benthic structures and water quality: carelessness in movements (Camp and Fraser, 2012; Gil et al., 2015; Hasler and Ott, 2008), touching the different sessile plant and animal species (Uyarra and Côté, 2007; Wilkinson and Souter, 2008), pollution from both littering and vessels (Danovaro et al., 2008; Dearden et al., 2007) are responsible for the gradual decline in habitat health or benthic species composition (Table 1a). The stress on the local environment caused by MWT increases the susceptibility of benthic communities to disease (Vignon et al., 2010), predation (Corcoran et al., 2013) and/or possibly contributes to a habitat shift toward more opportunistic and resilient species (Hawkins et al., 1999; Lloret et al., 2006; Nugues and Roberts, 2003; Schleyer and Tomalin, 2000). Pollution and increased nutrients due to frequent and large-scale provisioning are also factors likely to alter the structure and health of the local marine ecosystem (Dearden et al., 2007; Saphier and Hoffmann, 2005; Turner and Ruhl, 2007; Wilkinson 2008). Coastal habitats/ecosystems are also subjected to other forms of tourism, leisure activities, development and industries (Davenport and Davenport, 2006; Hall, 2001). The consequences recorded for MWT are thus further enhanced by the combined and cumulative effect of several anthropogenic activities, which lead to a critical need for the development and enforcement of policies and management frameworks aiming at the conservation of marine/coastal ecosystems. However few studies have focused on the effects of MWT activities on local habitats: of the 396 papers reviewed only 20 (5\%) have addressed the topic. More information can be found related to the habitat effects of tourism in general, rather than MWT specifically, a fact that highlights a knowledge gap that needs to be urgently addressed, particularly given the relevance of habitat health on the wellbeing of all organisms inhabiting an area (Rosenberg et al., 2000).

\subsection{Sustainability of marine wildlife tourism}

There are cases where the combination of scientific-based knowledge, appropriate policies, enforcement of regulations and regular monitoring have allowed MWT to be considered ecologically sustainable, as detailed in Section 3.1 (Table 2). Such cases present reported evidence of lack of chronic/irreversible changes in the ecology of the species involved or in the ecosystem. Unfortunately the published scientific literature documenting such 'successful' cases is quite sparse (4.3\% of the MWT literature analysed). Nevertheless, the evaluation of successful cases can provide valuable information for the development of best practices and strategies for sustainable MWT. We present as example three case studies which meet all the criteria of success detailed in Section 3.1, and have been able to contribute to the preservation of the species involved while allowing the development of a touristic activity.

\section{Table 2}

Studies documenting ecologically successful cases of MWT around the globe, and common management features shared by them with regards to target species conservation.

\begin{tabular}{|c|c|c|}
\hline \multicolumn{3}{|c|}{ Documented 'successful' cases of marine wildlife tourism } \\
\hline MWT activity & Species & References \\
\hline Shark-watching & $\begin{array}{l}\text { Grey Nurse Shark } \\
\text { (Carcharias taurus) } \\
\text { Whale Shark } \\
\text { (Rhincodon typus) }\end{array}$ & $\begin{array}{l}\text { Apps et al., 2015; Barker et al., 2011a; } \\
\text { Mau, 2008; Smith et al., 2010; Smith et } \\
\text { al., } 2014\end{array}$ \\
\hline Whale-watching & $\begin{array}{l}\text { Dwarf Minke Whale } \\
\text { (Balaenoptera } \\
\text { acutorostrata) } \\
\text { Humpback Whale } \\
\text { (Megaptera } \\
\text { novaeangliae) }\end{array}$ & $\begin{array}{l}\text { Arnold and Birtles, 1999; Birtles et al., } \\
\text { 2002a, 2002b; Birtles et al., 2005; } \\
\text { Birtles et al., 2008; Birtles et al., 2014, } \\
\text { Wilson, } 2003\end{array}$ \\
\hline Turtle-watching & $\begin{array}{l}\text { Atlantic Green Turtle } \\
\text { (Chelonia mydas) } \\
\text { Hawksbill Sea Turtle } \\
\text { (Eretmochelys } \\
\text { imbricata) } \\
\text { Leatherback Sea } \\
\text { Turtle (Dermochelys } \\
\text { coriacea) } \\
\text { Loggerhead Sea Turtle } \\
\text { (Caretta caretta) }\end{array}$ & $\begin{array}{l}\text { Meletis and Harrison, 2010; Tisdell and } \\
\text { Wilson, 2002a, 2002b; } \\
\text { Tisdell and Wilson, 2005b }\end{array}$ \\
\hline SCUBA-diving & N/A (reef ecosystem) & Lee, 2013; Rosales, 2006 \\
\hline
\end{tabular}

Shared management features*

Presence of official policies to ensure species/habitat's conservation

Strict limitations in sites accessibility: time, areas, licenses, number of tourists allowed Structured management

Clear education of operators and tourists on existing policies

Monitoring of compliance with policies

Enforcement of regulations and fining or reporting to competent authorities in case of breach

Prohibition of behaviour/objects that might be a source of stress or damage for the animal

Monitoring of animal's behaviour to detect signs of stress/disturbance Adaptive management approach

Environmental assessments and strategic planning prior to and following the establishment of the MWT activity

Involvement of local communities in decision making

Promotion of scientific research on ecology/physiology of target species

Operators' involvement in scientific research on target species

Enhancement of tourists' ecological awareness through education

* Detailed information on the policies developed and enforced for each 'successful' case of MWT is reported in Appendix 3.

\subsubsection{EXAMPLE 1 - grey nurse shark (Eastern Australia)}

Detailed guidelines/codes of conduct (see Box 1 for definitions), together with the almost complete compliance from divers, led to the gradual development of tourism interactions with the critically endangered grey nurse shark (Carcharias taurus) in Eastern Australia (Smith et al., 2014). Monitoring studies have reported the absence of significant changes in behaviour or occurrence/density of grey nurse sharks, despite the regular and frequent encounters with divers (Barker et al., 2011a; Smith et al., 2010). The integration of scientific data on the ecology of these sharks with information gathered on participants' perception and behaviour has allowed to improve shark-divers interactions through the development of an adaptive management framework (Apps et al., 2015) with strict regulations aimed at protecting the sharks from being disturbed while allowing tourist activities (Barker et al., 2011a; Smith et al., 2010).

\subsubsection{EXAMPLE 2 - minke whale (Northern Australia)}

In the Northern sections of the Great Barrier Reef (GBR) Marine Park, Australia, whale-watching organizations have developed an effective system for swimming with dwarf minke whales (Balaenoptera acutorostrata) with minimum or no observed negative impact on the presence and behaviour of the cetaceans (Birtles et al., 2002a; Birtles 
and Mangott, 2013). The animals were found to voluntarily approach slow moving/stationary vessels and swimmers (Birtles and Mangott, 2013), which would indicate a lack of disturbance from this tourism activity and even interest or curiosity on behalf of the cetaceans involved (Birtles et al., 2002a; Birtles et al., 2014). Limited vessel presence (a maximum of 6 permits per year are released), highly managed swimmer behaviour and strict regulations concerning the duration of the encounters as well as speed, direction and distance from the whales, allow for the animals to carry on with their activities and dictate the terms of the interaction (Birtles et al., 2002a; Birtles et al., 2014). Despite the lack of information about the biology and ecology of these animals, the measures described above and the prevention principle employed at the early stages of development of this particular activity have allowed for the development of a popular and successful MWT that does not appear to negatively affect the health of the animals involved (Birtles et al., 2002a).

\subsubsection{EXAMPLE 3 - sea turtles (Costa Rica, Australia, etc.)}

A multi-location example of sustainable MWT is sea turtle tourism. The site-specific habitat use patterns of sea turtles (i.e. predictable use of nesting beaches and foraging grounds) means that turtle-human interaction rates can be high. The highest volumes of people interacting with sea turtles normally occur at nesting beaches, where tourists observe female turtles laying eggs. This activity is practiced in several locations around the globe with regulations developed and enforced to ensure the safety and wellbeing of the turtles and the eggs, e.g. Tortuguero in Costa Rica (Meletis and Harrison, 2010) and Mon Repos in Australia (Wilson, 2003). Because of the existence of strict guidelines and codes of conduct based on scientific information and adjusted on direct observations from operators, this form of tourism has been refined over time to minimize impact on the behaviour and health of the animals involved (Meletis and Harrison, 2010; Wilson, 2003).

Although there is not much information published in primarily literature (Landry and Taggart, 2010; Wilson, 2003), many sea turtle tourism ventures employ similar codes of conduct. Online searches for "turtle watching guidelines" show a plethora of locations that have comparable set guidelines.

\subsection{Recurring issues in marine wildlife tourism}

Regardless of the existence of positive examples such as those highlighted previously, our review identified several common issues among MWT practices that can hinder the proper development of an ecologically sustainable tourism. These include knowledge gaps, poor management frameworks, and lack of enforcement and implementation of best practices.

\subsubsection{Lack of background information and baseline data}

Comprehensive knowledge on the biology, ecology and behaviour of a particular species or population is not always available, due to reasons that can range from mere lack of baseline/long-term data to logistical difficulties associated with the collection of information (e.g. species that move over large ranges or unknown habits) (Birtles and Mangott, 2013; Clarke et al., 2011). Information on species' biology and ecology is essential for a timely detection of signs of negative impacts such as alteration of health, behaviour, distribution, and population dynamics. With such knowledge it is possible to develop best courses of action to eliminate the source of disturbance through timely intervention and appropriate policies/management frameworks and ensure increased conservation benefits for the species and habitat involved (Birtles and Mangott, 2013; Gallagher et al., 2015; Schaffar et al., 2009). For many species and locations, best practices and codes of conduct are however generated by operators based on their experience and personal observations, or on management tools employed in similar MWT practices, but they often lack the required scientific grounding (Birtles and Mangott, 2013; Clarke et al., 2011; Landry and Taggart, 2010). While such regulations might be a first step in establishing a correct management plan for a MWT activity, the lack of specific information on the target species as well as lack of long-term monitoring of the effects of tourism might lead to the implementation of ineffective guidelines and measures, thus deviating from the long-term sustainability goal of MWT.

\subsubsection{Lack of physiological data}

The lack of physiological information is one of the biggest gaps in understanding and managing the impacts from tourism, and probably one of the hardest issues to address. Of the 396 studies reviewed, only 10 focused on physiology. Behavioural studies have provided important evidence of the existence of negative impacts of MWT on marine species (e.g. Cubero-Pardo et al., 2011; Granquist and Sigurjonsdottir, 2014; Quiros, 2007) (Table 1a). However, there are instances where such information is not sufficient or might even be misleading. Changes in behaviour do not necessarily indicate poor health, and there are also cases where the health of the individual is negatively affected but there are no visible signs or behavioural manifestations to indicate it (Beale and Monaghan, 2004; Bejder et al., 2009; Gill et al., 2001). The few physiological studies conducted so far have contributed to determine whether the health of the animals and overall population fitness are compromised (e.g. French et al., 2011) (Table 1a). In the long-term this could possibly lead to selection against sensitive individuals (Bejder et al., 2006; IWC, 2006; Lusseau and Bejder, 2007), a topic of particular concern considering the 'threatened' or 'endangered' status of some of the species involved (Hoyt, 2001; Quiros, 2007). Collecting data on the physiology of the target animals can be extremely difficult due to the nature of the sampling procedures and often lack of baseline data to use as reference. However, knowledge of physiological thresholds and indicators of health for the species involved in MWT are essential for the detection of negative impacts at individual and population level, and resolve if evident behavioural changes result in detrimental flow on effects to health. Integrating such information in MWT management is a fundamental step toward the development of suitable policies and monitoring frameworks to reduce as much as possible negative health implications on the target species and ensure proclaimed conservation benefits are realistic.

\subsubsection{Poor management and frameworks}

The sole presence of extensive scientific knowledge is not however sufficient for the sustainable development of marine tourism. Inadequate frameworks and guidelines (e.g. excessive vessel allowances, underestimate of the limit distance from the animals, unsupervised behaviour of the tourists, etc.) coupled with lack of enforcement are also responsible for the several negative impacts of MWT on target species (Constantine et al., 2004; Parsons, 2012; Sitar et al., 2016; Wiley et al., 2008).

The maximum capacity of a particular habitat, the tolerance limits of the species involved and the long-term impacts of a MWT activity can sometimes be overlooked (intentionally or not) during the development of the management frame, sometimes simply to give priority to the socio-economic goals (Bearzi, 2007; Steckenreuter et al., 2012; Van Waerebeek et al., 2007).

The presence of unclear regulations or the discontinuity between international, national and local policies is also likely to result in the decreased efficacy of such management tools. Conflicts of interest, overlapping of jurisdiction, the existence of several codes of conduct and lack of coordination between different stakeholders are also issues that indirectly contribute to the downsides associated with MWT (Garrod and Fennell, 2004; Parsons, 2012; Wiley et al., 2008).

Moreover, the contrast between the different interests and priorities of the stakeholders involved in the development/management of a MWT, coupled with a lack of clear terminology (i.e. definitions of 'successful', 'ecologically/environmentally sustainable', etc.), are likely contributors to the divergence of goals and ineffectiveness of management strategies, particularly those aiming at ensuring the long-term 
health and conservation of MWT species and ecosystems (Adams et al., 2003; Newsome et al., 2005; Swarbrooke, 1999).

\subsubsection{Lack of proper implementation and enforcement}

Good management plans and guidelines have no value if they are not adequately implemented (Parsons, 2012; Pavez et al., 2015; Sitar et al., 2016; Wiley et al., 2008). Large-scale monitoring of visitors' behaviour and enforcement of regulations are not always feasible due to logistic and economic constraints, and in many cases the management and implementation of guidelines/restrictions takes place at a smaller, local scale (Allen et al., 2007; Constantine et al., 2004; Dobson, 2006). Unfortunately, lack of coordination between operators, lack of compliance from the different stakeholders - including the operators themselves (Parsons, 2012; Pavez et al., 2015; Wiley et al., 2008) - and a greater interest in the economic exploit of the resource rather than in its conservation (Parsons, 2012; Steckenreuter et al., 2012; Van Waerebeek et al., 2007) are not infrequent, and hinder greatly the development of ecologically successful MWT practices. These factors coupled with ignorance of the consequences of tourists' actions and unmanaged behaviour of both visitors and operators frequently leads to chronic disturbances and stress on the environment (Garrod and Fennell, 2004; Shaalan, 2005; Zeppel, 2009).

\subsubsection{Lack of consideration of the social context of MWT destinations}

Engaging locals as stakeholders in tourism development is essential to ensure sustainability in nature-based tourism as well as maintain consideration of the values and needs of the local communities and increase awareness/engagement for the conservation of the species and habitats involved in MWT (Agardy, 1993; Wilson, 2003). The potential for rapid or unregulated tourism development to lead to social impacts on local populations and to destination decline has been well documented in the broader tourism literature (e.g. Butler, 1980; Diedrich and García-Buades, 2009). However, the local social dimension receives surprisingly little attention in the MWT literature. Rather, MWT studies tend to focus on evaluating the satisfaction or characteristics of tourists (e.g. Ballantyne et al., 2009, Catlin and Jones, 2010) or on mitigating impacts on marine wildlife (e.g. Bravo et al., 2015, Cassini et al., 2004). While these factors are undeniably important, failure to consider the existing socio-economic and cultural context of the destination where MWT is occurring could lead to negative repercussions in the local population as well, which, in turn, can have negative impacts on marine wildlife and on tourists. For example, in fishing dependent communities, tourism can create conflict and resentment for conservation measures associated with MWT sustainability among local people if they feel they are losing control and access to natural resources (e.g. Bennett and Dearden, 2014). Tortuguero National Park in Costa Rica is well known for its success in balancing MWT and marine turtle conservation; but several violent conflicts have occurred between foreign volunteers and illegal poachers, which has negatively impacted its reputation as a tourism destination (The Washington Post, 2013). The desirable alternative is that MWT, through its associated benefits, will generate alternative livelihoods and reduce harvest/consumption of marine resources, thus promoting local awareness and support for conservation measures (e.g. Diedrich, 2007; Wilson, 2003).

\subsection{Strategies for effective management of marine wildlife tourism}

The combination of socio-economic and ecological knowledge is essential for the development of adequate management frameworks that aim at the long-term ecological sustainability of MWT in addition to a profitable income. Several recommendations and possible directions for management and research have been proposed and introduced in the literature, many of which recur across the different forms of MWT (Fig. 1; Appendix 2).

Elements such as long-term monitoring, stricter regulations and increased ecological awareness of both operators and visitors can be applied to different contexts, independently from the location or the target species/habitat. The development and application of such strategies and best practices requires however considerable knowledge of the organisms and ecosystems involved. Based on the literature available it is evident that more physiological studies and monitoring assessments are required to cover the knowledge gap related to MWT. Given that studies of this type are often difficult to carry out (particularly for marine species) and require time, it would be best in the meantime to adopt a precautionary approach in the management of the interaction between tourist and animals (e.g. Gallagher et al., 2015; Richards et al., 2015), a prime example being the minke whale tourism (see Section 3.3.2). This issue is not unique of marine tourism, but common also to other recreational activities, like sportfishing (Kieffer, 2000; Meka and McCormick, 2005; Suski et al., 2004). Nevertheless, the rapidly increasing number of studies and literature available on the subject, coupled with the growing interest from the public, are a promising sign of the effort aimed at addressing this knowledge gap.

A further step that can be taken to improve MWT is the application of the core elements of successful cases to other forms of marine tourism to improve their long-term sustainability (Table 2; Appendix 3). As the sea turtle nesting industry has demonstrated, common regulations can be developed and implemented leading to positive outcomes, despite the geographical, cultural and socio-economical differences existing between locations (e.g. Costa Rica vs. Mon Repos). The application of such elements should not be limited to the same form of marine tourism: principles and management guidelines from turtle tourism could be adapted and applied to other forms of wildlife tourism. For example: identifying a limit distance for approach, establishing restricted areas for tourism presence, keeping the visitors in small controlled groups, and prohibition of direct approach or any behaviour that could disturb the animals are all policies employed in turtle tourism that can be readily applied to any other form of MWT.

Based on the evaluation of the existing literature, the recorded cases of successful and sustainable marine wildlife tourism all share the implementation of an adaptive management framework (Fig. 2), which is characterised by five major points:

1) A well organised management plan of the activity, where the socio-economic and ecologic aims of the MWT practice as well as the roles of the different stakeholders are clearly delineated.

2) The development of clear policies/guidelines based on current scientific knowledge and direct on-field observations.

3 ) The structured and strict enforcement of said rules on behalf of the operators and, where possible, official local/governmental authorities, coupled with the active education of tourists.

4) Long-term monitoring of the effects of the MWT practice on the environment and target species to provide researchers and stakeholders with information required to adequately upgrade the policies and management frames implemented (feedback mechanism).

5) An active effort at increasing the ecological awareness, education and involvement of both tourists and operators in the conservation of the species/habitat involved in the MWT practice (thus reducing the risk of accidental negative impacts on the environment).

These steps should be taken into consideration when planning the development of a MWT practice, or integrated in the management of existing marine tourism activities. Several models, approaches, and frames for management have in fact been proposed in the past to address the issue of tourism impact on the environment while at the same time allowing for economic and social growth (Barker and Roberts, 2004; Higham et al., 2008; Rouphael and Hanafy, 2007). Their implementation however, often results non-viable for reasons that range from costs and time limitation to socio-economic issues (Dobson, 2006; Harriott et al., 1997; Parsons, 2012; Pirotta and Lusseau, 2015).

Generalised regulations and strategies however are not always sufficient for the proper development of a marine touristic activity. The diversity between different forms of MWT, and even within the 


\section{Recommendations for Management and Research}

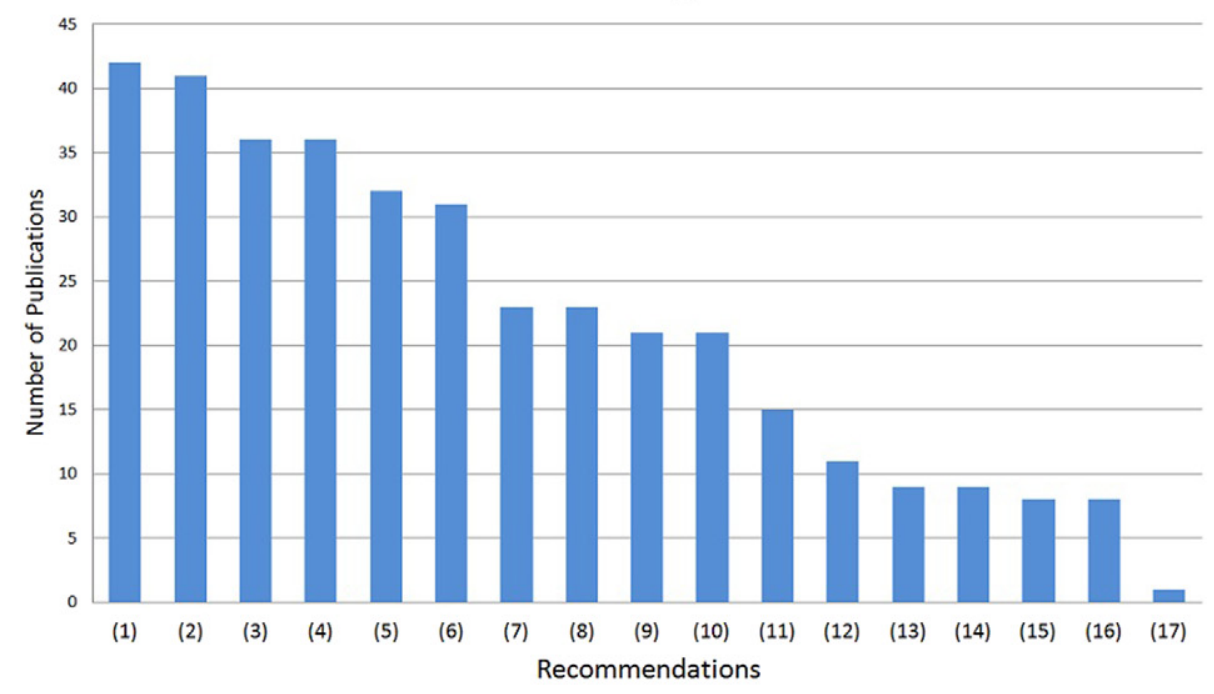

\begin{tabular}{|l|}
\hline Recommendations \\
\hline (1) Long-term monitoring of effects and ecosystem health \\
\hline (2) Control of access: careful and strict regulation of number of visitors and \\
duration/frequency/closeness of encounters \\
\hline (3) Structured and official enforcement of regulations \\
\hline (4) Increase ecological awareness and education of visitors and operators \\
\hline (5) Clear management frameworks \\
\hline (6) Monitoring and regulation of visitors' behaviour \\
\hline (7) Creation of specific guidelines, protocols and codes of conduct based on scientific knowledge \\
and case-specific observations \\
\hline (8) Increase of scientific research on the ecology and physiology of species/habitats involved in \\
MWT \\
\hline (9) Adaptive Management: feedback mechanisms to improve management frameworks with \\
information collected through monitoring \\
\hline (10) Promotion of stakeholders involvement and collaboration \\
\hline (11) Clear understanding of the ecological strength and weaknesses of each touristic site/species \\
to create appropriate management frames \\
\hline (12) Detailed information on the ecological, social, economic, and touristic demands as well as \\
requirements involved in each site/case \\
\hline (13) Creation of seasonal or permanent no-go areas \\
\hline (14) Entrance fees to provide funds for research, management and enforcement \\
\hline (15) Creation of infrastructures that reduce risk of habitat damage \\
\hline (16) Precautionary approach in absence of clear data \\
\hline (17) Development of prediction models and simulation platforms to account for all the different \\
components in the management of MWT (ecologic, economic, social, etc.) \\
\hline
\end{tabular}

Fig. 1. Occurrence of the most popular recommendations for management and research in the MWT literature (for more details see Appendix 2).

same type of activity, requires the guidelines to be adjusted to the situation (Constantine and Bejder, 2008; Higham et al., 2008; Pirotta and Lusseau, 2015). Characteristics such as location, species involved, environmental factors, tourist demand and pressure, local socio-economic factors, and so forth, must be taken into account when developing and analysing a marine touristic activity. Different strategies and tailored management that actively involve all the interested stakeholders are therefore an essential component of MWT development.

Another factor to be addressed when generating a long-term management framework is the different scales at which this type of tourism takes place (Fig. 3). Given the complexity and wide distribution of marine tourism around the world, each different form of this activity should be analysed at different levels: Global, National and Local (Fig. 3). This would allow various issues to be addressed at their appropriate scale and develop suitable solutions.

\section{Conclusions}

There is still quite a way to go before marine tourism around the world can be considered an effective, long-term sustainable activity from both an economic and ecological point of view. We are not saying that marine tourism is failing in its attempt to be ecologically sustainable as well as profitable. On the contrary, as a world-wide industry facing a diversity challenges due to its inherent characteristics and variability, the work dedicated at all levels (operators, managers, scientists, tourists, etc.) to reduce negative impacts has been and still is quite extensive, and has proven in several occasions to lead to positive outcomes (Bramwell and Lane, 2000; Davis and Gartside, 2001; Dolnicar et al., 2008; Miller et al., 2010; Swarbrooke, 1999).

In many cases, the problems associated with marine tourism are not the result of direct malpractice or absence of regulations, but rather the consequence of 1) lack of proper structure and 


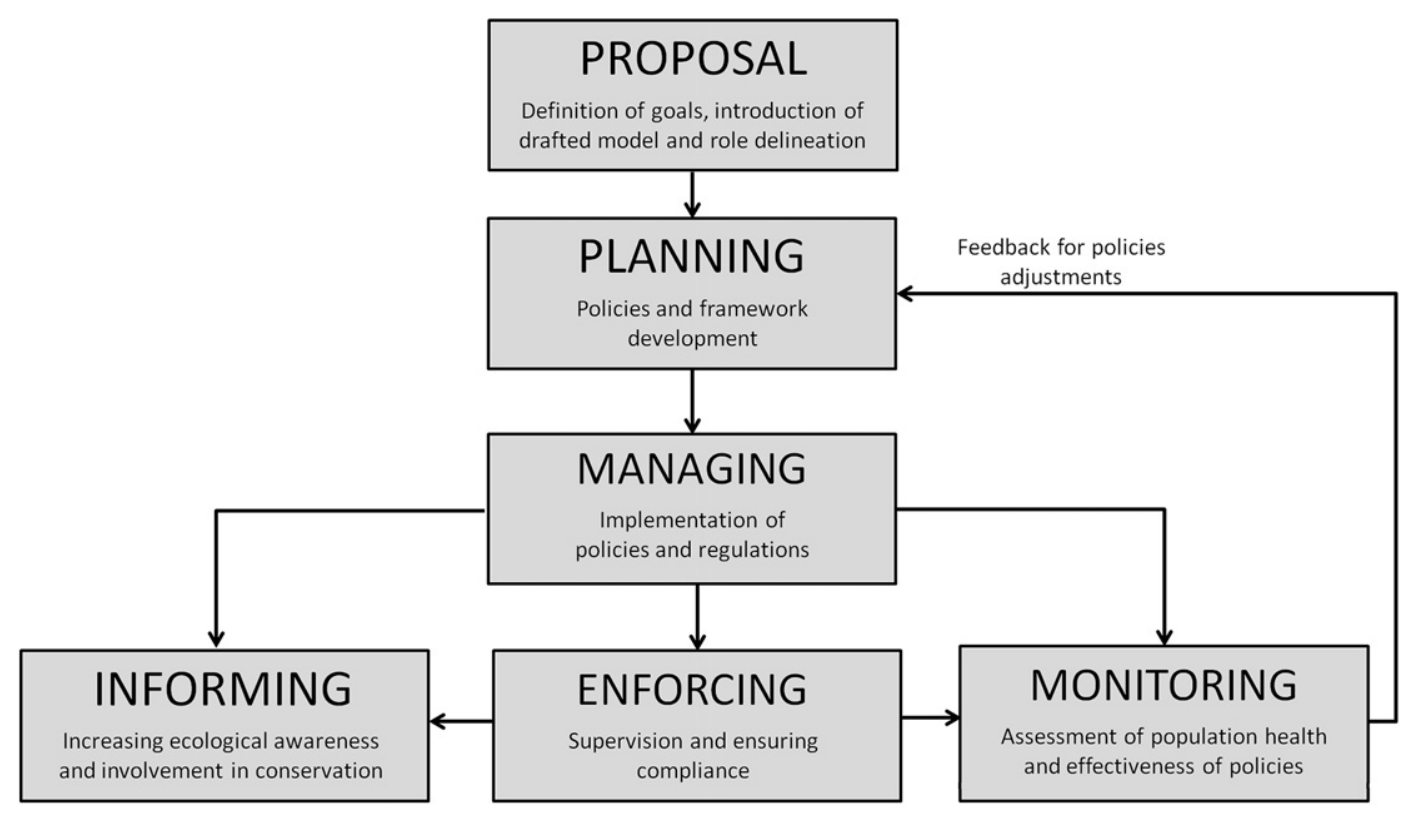

Fig. 2. Characteristics of MWT policies and management strategies at three different scales: global, national and local.

coordination, 2) conflicting/ineffective policies (due to being developed without proper scientific knowledge on the species and habitat involved), or 3) lack of enforcement of set regulations. These factors need to be taken into account and properly addressed when developing or managing MWT, particularly when considering that the ecological sustainability of any marine tourism activity varies on a case-to-case basis based on the combination of such factors and how well they are addressed.

There are still issues concerning negative effects of MWT that need to be addressed, but as demonstrated by the examples of successful cases it is possible to find an adequate solution for such issues, or at least mitigate the related downsides and therefore increase the likelihood of MWT providing tangible conservation benefits. To ensure the development of suitable policies, frameworks and management strategies for MWT activities that would ensure the achievement of both economic and conservation objectives, collaboration among stakeholders should focus on:

- Increase research effort on the biology, ecology and behaviour of the species/habitat involved, with particular focus on establishing suitable indicators of health and enable early detection of negative impacts linked to MWT. Often data collection can be integrated in the MWT activity and carried out by operators and researchers.

- Integration of the knowledge obtained through research in the planning phase of MWT practices as well as in the update/improvement process of existing policies (adaptive management framework).

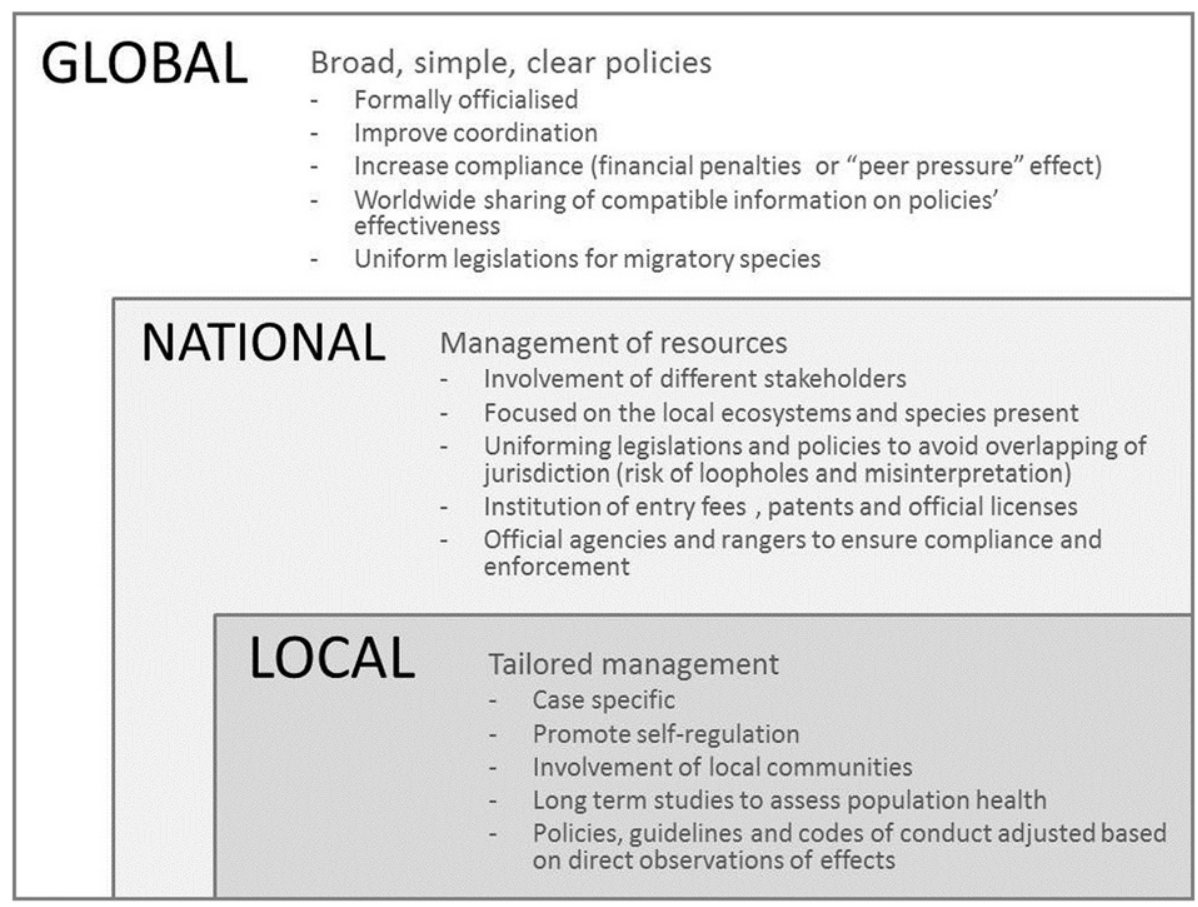

Fig. 3. Adaptive management framework for marine tourist activities. 
- Focus on reducing the observed negative impacts of MWT practices through prevention as well as improving existing frameworks: a) Increase education and ecological awareness of operators and visitors regarding the local species/habitat, b) Involve local communities in preserving their natural assets through non-consumptive activities and adequate management of MWT, and c) ensure the enforcement of policies by MWT operators and local authorities.

- Apply the five core elements of adaptive management framework (as described in Section 3.5) from the planning phase of MWT, if possible.

- Evaluate the possibility to implement conceptual elements, existing policies and frameworks from reported 'successful' cases, in the structure of other MWT cases/activities by adapting them to the specific circumstances of each case.

- Increase the consideration of scale (Fig. 3) as well as MWT type, geographical-, and species-specific characteristics during the planning phase of each MWT activity and the development/improvement process of policies to ensure their applicability and maximize success on a case-specific level.

Management of marine touristic activities is not a static process. It is only with the active participation of all the different parties involved (i.e. governments, management agencies, researchers and scientists, operators, and local communities) in the main stages of any marine touristic industry - planning, managing and monitoring (Fig. 2) - that it is possible to work toward the betterment of MWT and ensure its long-term ecological sustainability. Information sharing, planning and cooperation at all levels of development and management are essential for the success of this endeavour.

Supplementary data to this article can be found online at http://dx. doi.org/10.1016/j.biocon.2017.02.020.

\section{References}

Adams, W.M., Brockington, D., Dyson, J., Vira, B., 2003. Managing tragedies: understanding conflict over common pool resources. Science 302 (5652), 1915-1916.

Agardy, T., 1993. Accommodating ecotourism in multiple use planning of coastal and marine protected areas. Ocean Coast. Manag. 20, 219-239.

Allen, S., Smith, H., Waples, K., Harcourt, R., 2007. The voluntary code of conduct for dolphin watching in Port Stephens, Australia: is self-regulation an effective management tool? J. Cetacean Res. Manag. 9 (2), 159-166.

Andersen, S.M., Teilmann, J., Dietz, R., Schmidt, N.M., Miller, L.A., 2012. Behavioural responses of harbour seals to human-induced disturbances. Aquat. Conserv. 22 (1), $113-121$.

Anderson, D.W., Keith, J.O., 1980. The human influence on seabird nesting success: conservation implications. Biol. Conserv. 18 (1), 65-80.

Apps, K., Lloyd, D., Dimmock, K., 2015. Scuba diving with the grey nurse shark (Carcharias taurus): an application of the theory of planned behaviour to identify divers beliefs. Aquat. Conserv. Mar. Freshwat. Ecosyst. 25 (2), 201-211.

Araujo, G., Lucey, A., Labaja, J., So, C.L., Snow, S., Ponzo, A., 2014. Population structure and residency patterns of whale sharks, Rhincodon typus, at a provisioning site in Cebu, Philippines. Peer] 2, e543.

Arnold, P.W., Birtles, R.A., 1999. Towards sustainable management of the developing dwarf minke whale tourism industry in northern Queensland. CRC Reef Research Centre Technical Report No. 27. CRC Reef Research Centre, Townsville (30 pp).

Ballantyne, R., Packer, J., 2013. International Handbook on Ecotourism. Edward Elgar Publishing.

Ballantyne, R., Packer, J., Hughes, K., 2009. Tourists' support for conservation messages and sustainable management practices in wildlife tourism experiences. Tour. Manag. 30 (5), 658-664.

Barker, N.H., Roberts, C.M., 2004. Scuba diver behaviour and the management of diving impacts on coral reefs. Biol. Conserv. 120 (4), 481-489.

Barker, S.M., Peddemors, V.M., Williamson, J.E., 2011a. A video and photographic study of aggregation, swimming and respiratory behaviour changes in the grey nurse shark (Carcharias taurus) in response to the presence of SCUBA divers. Mar. Freshw. Behav. Physiol. 44, 75-92.

Barker, S.M., Peddemors, V.M., Williamson, J.E., 2011b. Recreational SCUBA diver interactions with the critically endangered grey nurse shark Carcharias taurus. Pac. Conserv. Biol. 16, 261-269.

Barnett, A., Payne, N.L., Semmens, J.M., Fitzpatrick, R., 2016. Ecotourism increases the field metabolic rate of whitetip reef sharks. Biol. Conserv. 199, 132-136.

Beale, C.M., Monaghan, P., 2004. Behavioural responses to human disturbance: a matter of choice? Anim. Behav. 68 (5), 1065-1069.

Bearzi, G., 2007. Marine conservation on paper. Conserv. Biol. 21 (1), 1-3.
Bejder, L., Samuels, A., Whitehead, H., Gales, N., 2006. Interpreting short-term behavioural responses to disturbance within a longitudinal perspective. Anim. Behav. 72 (5), 1149-1158

Bejder, L., Samuels, A., Whitehead, H., Finn, H., Allen, S., 2009. Impact assessment research: use and misuse of habituation, sensitisation and tolerance in describing wildlife responses to anthropogenic stimuli. Mar. Ecol. Prog. Ser. 395, 177-185.

Bennett, N.J., Dearden, P., 2014. Why local people do not support conservation: community perceptions of marine protected area livelihood impacts, governance and management in Thailand. Mar. Policy 44, 107-116.

Birtles, A., Mangott, A., 2013. Highly interactive behaviour of inquisitive dwarf minke whales. Whales and Dolphins: Cognition, Culture, Conservation and Human Perceptions, p. 140.

Birtles, R.A., Arnold, P.W., Dunstan, A., 2002a. Commercial swim programs with dwarf minke whales on the northern Great Barrier Reef, Australia: some characteristics of the encounters with management implications. Aust. Mammal. 24, 23-38.

Birtles, A., Valentine, P., Curnock, M., Arnold, P., Dunstan, A., 2002b. Incorporating visitor experiences into ecologically sustainable dwarf minke whale tourism in the northern Great Barrier Reef. CRC Reef Research Centre Technical Report No 42. Townsville, CRC Reef Research Centre Ltd.

Birtles, A., Curnock, M., Dobbs, K., Smyth, D., Arnold, P., Marsh, H., Charles, D., 2005. Code of Practice for the Sustainable Management of Dugong and Marine Turtle Tourism in Australia.

Birtles, A., Arnold, P., Curnock, M., Salmon, S., Mangott, A., Sobtzick, S., Valentine, P., Caillaud, A., Rumney, J., 2008. Code of Practice for dwarf minke whale interactions in the Great Barrier Reef World Heritage Area. Great Barrier Reef Marine Park Authority, Townsville, Australia.

Birtles, A., et al., 2014. Report to the Great Barrier Reef Marine Park Authority on the Dwarf Minke Whale Tourism Monitoring Program (2003-2008), Research Publication 112. GBRMPA. Townsville.

Blane, J.M., Jaakson, R., 1994. The impact of ecotourism boats on the St Lawrence beluga whales. Environ. Conserv. 21 (03), 267-269.

Bramwell, B., Lane, B., 2000. Tourism Collaboration and Partnerships: Politics, Practice and Sustainability. Vol. 2. Channel View Publications.

Bravo, G., Marquez, F., Marzinelli, E.M., Mendez, M.M., Bigatti, G., 2015. Effect of recreational diving on Patagonian rocky reefs. Mar. Environ. Res. 104, 31-36.

Brooks, E.J., Sloman, K.A., Liss, S., Hassan-Hassanein, L., Danylchuk, A.J., Cooke, S.J., ... Suski, C.D., 2011. The stress physiology of extended duration tonic immobility in the juvenile lemon shark, Negaprion brevirostris (Poey 1868). J. Exp. Mar. Biol. Ecol. 409 (1) 351-360.

Brunnschweiler, J.M., 2010. The shark reef marine reserve: a marine tourism project in Fiji involving local communities. J. Sustain. Tour. 18 (1), 29-42.

Brunnschweiler, J.M., Barnett, A., 2013. Opportunistic visitors: long-term behavioural response of bull sharks to food provisioning in Fiji. PLoS One 8 (3), e58522.

Brunnschweiler, J.M., Abrantes, K.G., Barnett, A., 2014. Long-term changes in species composition and relative abundances of sharks at a provisioning site. PLoS One 9 (1), e86682.

Bryant, L., 1994. Report to Congress on results of feeding wild dolphins, 1989-1994. National Marine Fisheries Service, Office of Protected Resources.

Burger, J., Gochfeld, M., 1993. Tourism and short-term behavioural responses of nesting masked, red-footed, and blue-footed boobies in the Galapagos. Environ. Conserv. 20 (3), 255-259.

Burger, J., Gochfeld, M., Niles, L.J., 1995. Ecotourism and birds in coastal New Jersey: contrasting responses of birds, tourists, and managers. Environ. Conserv. 22 (01), 56-65.

Burgin, S., Hardiman, N., 2015. Effects of non-consumptive wildlife-oriented tourism on marine species and prospects for their sustainable management. J. Environ. Manag. $151,210-220$.

Butler, R., 1980. The concept of a tourist area life cycle of evolution: implications for management of resources. Can. Geogr. 1, 5-12.

Camp, E., Fraser, D., 2012. Influence of conservation education dive briefings as a management tool on the timing and nature of recreational SCUBA diving impacts on coral reefs. Ocean Coast. Manag. 61, 30-37.

Cassini, M.H., Szteren, D., Fernández-Juricic, E., 2004. Fence effects on the behavioural responses of South American fur seals to tourist approaches. J. Ethol. 22, 127-133.

Catlin, J., Jones, R., 2010. Whale shark tourism at Ningaloo Marine Park: a longitudinal study of wildlife tourism. Tour. Manag. 31 (3), 386-394.

Christiansen, F., Rasmussen, M., Lusseau, D., 2013. Whale watching disrupts feeding activities of minke whales on a feeding ground. Mar. Ecol. Prog. Ser. 478, 239-251.

Clarke, C., Lea, J.S.E., Ormond, R.F.G., 2011. Reef-use and residency patterns of a baited population of silky sharks, Carcharhinus falciformis, in the Red Sea. Mar. Freshw. Res. 62 (6), 668-675.

Clarke, C.R., Lea, J.S.E., Ormond, R.F.G., 2013. Changing relative abundance and behaviour of silky and grey reef sharks baited over 12 years on a Red Sea reef. Mar. Freshw. Res. 64, 909-919.

Clua, E., Buray, N., Legendre, P., Mourier, J., Planes, S., 2010. Behavioural response of sicklefin lemon sharks Negaprion acutidens to underwater feeding for ecotourism purposes. Mar. Ecol. Prog. Ser. 414, 257-266.

Constantine, R., Bejder, L., 2008. 17 managing the whale-and dolphin-watching industry: time for a paradigm shift. Marine Wildlife and Tourism Management: Insights From the Natural and Social Sciences. 321.

Constantine, R., Brunton, D.H., Dennis, T., 2004. Dolphin-watching tour boats change bottlenose dolphin (Tursiops truncatus) behaviour. Biol. Conserv. 117 (3), 299-307.

Corcoran, M.J., Wetherbee, B.M., Shivji, M.S., Potenski, M.D., Chapman, D.D., Harvey, G.M., 2013. Supplemental feeding for ecotourism reverses diel activity and alters movement patterns and spatial distribution of the southern stingray, Dasyatis americana. PLoS One 8 (3), e59235. 
Cubero-Pardo, P., Herrón, P., González-Pérez, F., 2011. Shark reactions to scuba divers in two marine protected areas of the Eastern Tropical Pacific. Aquat. Conserv. Mar. Freshwat. Ecosyst. 21 (3), 239-246.

Cunningham-Smith, P., Colbert, D.E., Wells, R.S., Speakman, T., 2006. Evaluation of human interactions with a provisioned wild bottlenose dolphin (Tursiops truncatus) near Sarasota Bay, Florida, and efforts to curtail the interactions. Aquat. Mamm. 32 (3), 346-356

Danovaro, R., Bongiorni, L., Corinaldesi, C., Giovannelli, D., Damiani, E., Astolfi, P., ... Pusceddu, A., 2008. Sunscreens cause coral bleaching by promoting viral infections. Environ. Health Perspect. 116 (4), 441.

Davenport, J., Davenport, J.L., 2006. The impact of tourism and personal leisure transport on coastal environments: a review. Estuar. Coast. Shelf Sci. 67 (1), 280-292.

Davie, P.S., Franklin, C.E., Grigg, G.C., 1993. Blood pressure and heart rate during tonic immobility in the black tipped reef shark, Carcharhinus melanoptera. Fish Physiol. Biochem. 12 (2), 95-100.

Davis, D., Gartside, D.F., 2001. Challenges for economic policy in sustainable management of marine natural resources. Ecol. Econ. 36 (2), 223-236.

Dearden, P., Bennett, M., Rollins, R., 2007. Perceptions of diving impacts and implications for reef conservation. Coast. Manag. 35 (2-3), 305-317.

Denkinger, J., Parra, M., Muñoz, J.P., Carrasco, C., Murillo, J.C., Espinosa, E., ... Koch, V., 2013. Are boat strikes a threat to sea turtles in the Galapagos Marine Reserve? Ocean Coast. Manag. 80, 29-35.

Di Franco, A., Milazzo, M., Baiata, P., Tomasello, A. Chemello, R., 2009. Scuba diver behaviour and its effects on the biota of a Mediterranean marine protected area. Environ. Conserv. 36 (01), 32-40.

Diedrich, A., 2007. The impacts of tourism on coral reef conservation awareness and support in coastal communities in Belize. Coral Reefs 26, 985-996.

Diedrich, A., García-Buades, E., 2009. Local perceptions of tourism as indicators of destination decline. Tour. Manag. 30 (4), 512-521.

Dobson, J., 2006. Sharks, wildlife tourism, and state regulation. Tour. Mar. Environ. 3 (1), $15-23$.

Dolnicar, S., Crouch, G.I., Long, P., 2008. Environment-friendly tourists: what do we really know about them? J. Sustain. Tour. 16 (2), 197-210.

Fabinyi, M., 2008. Dive tourism, fishing and marine protected areas in the Calamianes Islands, Philippines. Mar. Policy 32 (6), 898-904.

Fitzpatrick, R., Abrantes, K.G., Seymour, J., Barnett, A., 2011. Variation in depth of whitetip reef sharks: does provisioning ecotourism change their behaviour? Coral Reefs 30 569-908.

Fowler, Gene S., 1999. Behavioral and hormonal responses of Magellanic penguins (Spheniscus magellanicus) to tourism and nest site visitation. Biol. Conserv. 90 (2), 143-149.

French, S.S., González-Suárez, M., Young, J.K., Durham, S., Gerber, L.R., 2011. Human disturbance influences reproductive success and growth rate in California sea lions (Zalophus californianus). PLoS One 6, e17686.

Gallagher, A.J., Hammerschlag, N., 2011. Global shark currency: the distribution, frequency, and economic value of shark ecotourism. Curr. Issue Tour. 14 (8), 797e812.

Gallagher, A.J., Vianna, G.M.S., Papastamatiou, Y.P., Macdonald, C., Guttridge, T.L., Hammerschlag, N., 2015. Biological effects, conservation potential, and research priorities of shark diving tourism. Biol. Conserv. 184, 365-379.

Garrod, B., Fennell, D.A., 2004. An analysis of whale watching codes of conduct. Ann. Tour Res. 31 (2), 334-352.

Gill, J.A., Norris, K., Sutherland, W.J., 2001. Why behavioural responses may not reflect the population consequences of human disturbance. Biol. Conserv. 97 (2), 265-268.

Gil, M.A., Renfro, B., Figueroa-Zavala, B., Penié, I., Dunton, K.H., 2015. Rapid tourism growth and declining coral reefs in Akumal, Mexico. Mar. Biol. 162 (11), 2225-2233.

Granquist, S.M., Sigurjonsdottir, H., 2014. The effect of land based seal watching tourism on the haul-out behaviour of harbour seals (Phoca vitulina) in Iceland. Appl. Anim. Behav. Sci. 156, 85-93.

Green, R., Higginbottom, K., 2001. Negative Effects of Wildlife Tourism on Wildlife. CRC for Sustainable Tourism, Gold Coast.

Hall, C.M., 2001. Trends in ocean and coastal tourism: the end of the last frontier? Ocean Coast. Manag. 44 (9), 601-618.

Harding, R., 2006. Ecologically sustainable development: origins, implementation and challenges. Desalination 187 (1), 229-239.

Hardy, et al., 2002. Sustainable tourism; an overview of the concept and its position in relation to conceptualisations of tourism. J. Sustain. Tour. 10 (6), 475-496

Harriott, V.J., Davis, D., Banks, S.A., 1997. Recreational diving and its impact in marine protected areas in eastern Australia. Ambio 173-179.

Haskell, P.J., McGowan, A., Westling, A., Méndez-Jiménez, A., Rohner, C.A., Collins, K., .. Pierce, S.J., 2015. Monitoring the effects of tourism on whale shark Rhincodon typus behaviour in Mozambique. Oryx 49 (03), 492-499.

Hasler, H., Ott, J.A., 2008. Diving down the reefs? Intensive diving tourism threatens the reefs of the northern Red Sea. Mar. Pollut. Bull. 56 (10), 1788-1794.

Hawkins, J.P., Roberts, C.M., Van't Hof, T., De Meyer, K., Tratalos, J., et al., 1999. Effects of recreational scuba diving on Caribbean coral and fish communities. Biol. Conserv. $13,888-897$.

Higham, J.E.S., Bejder, L., Lusseau, D., 2008. An integrated and adaptive management model to address the long-term sustainability of tourist interactions with cetaceans. Environ. Conserv. 35 (04), 294-302.

Hines, A.H., Whitlatch, R.B., Thrush, S.F., Hewitt, J.E., Cummings, V.J., Dayton, P.K. Legendre, P., 1997. Nonlinear foraging response of a large marine predator to benthic prey: eagle ray pits and bivalves in a New Zealand sandflat. J. Exp. Mar. Biol. Ecol. 216 (1), 191-210.

Holmes, B.J., Neil, D.T., 2012. “Gift Giving” by wild bottle nose dolphins (Tursiops sp.) to humans at a wild dolphin provisioning program, Tangalooma, Australia. Anthrozoös 25 (4), 397-413.
Hoyt, E., 2001. Whale Watching 2001: Worldwide Tourism Numbers, Expenditures, and Expanding Socioeconomic Benefits. International Fund for Animal Welfare, Yarmouth Port, MA, USA (pp. ii-vi; 1-158).

Huveneers, C., Rogers, P.J., Beckmann, C., Semmens, J.M., Bruce, B.D., Seuront, L., 2013. The effects of cage-diving activities on the fine-scale swimming behaviour and space-use of white sharks. Mar. Biol. 160, 2863-2875.

International Whaling Commission, 2006. Report of the Workshop on the Comprehensive Assessment of Southern Hemisphere Humpback Whales. Paper SC/58/Rep 5 presented at the IWC Scientific Committee, St. Kitts and Nevis (June 2006).

Jameson, S.C., Ammar, M.S.A., Saadalla, E., Mostafa, H.M., Riegl, B., 1999. A coral damage index and its application to diving sites in the Egyptian Red Sea. Coral Reefs 18 (4), 333-339.

Jensen, F.H., Wahlberg, M., Bejder, L., Madsen, P.T., 2008. Noise levels and masking potential of small whale-watching and research vessels around two delphinid species. Bioacoustics 17 (1-3), 166-168.

Kieffer, J.D., 2000. Limits to exhaustive exercise in fish. Comp. Biochem. Physiol. A Mol. Integr. Physiol. 126 (2), 161-179.

Kovacs, A., Innes, S., 1990. The impact of tourism on harp seals (Phoca groenlandica) in the Gulf of St. Lawrence, Canada. Appl. Anim. Behav. Sci. 26, 25-36.

Landry, M.S., Taggart, C.T., 2010. "Turtle watching” conservation guidelines: green turtle (Chelonia mydas) tourism in nearshore coastal environments. Biodivers. Conserv. 19 (1), 305-312.

Laroche, R., Kock, A.A., Dill, L.M., Oosthuizen, W., 2007. Effects of provisioning ecotourism activity on the behaviour of white sharks Carcharodon carcharias. Mar. Ecol. Prog. Ser. 338, 199-209.

Lee, E., 2013. Comprehensive Tourism Management Plan.

Lloret, J., Marín, A., Marín-Guirao, L., Francisca Carreño, M., 2006. An alternative approach for managing scuba diving in small marine protected areas. Aquat. Conserv. Mar. Freshwat. Ecosyst. 16 (6), 579-591.

Luna, B., Pérez, C.V., Sánchez-Lizaso, J.L., 2009. Benthic impacts of recreational divers in a Mediterranean Marine Protected Area. ICES J. Mar. Sci.: J. Conseil. 66 (3), 517-523.

Lusseau, D., Bejder, L., 2007. The long-term consequences of short-term responses to disturbance experiences from whale-watching impact assessment. Int. J. Comp. Psychol. $20(2)$.

Mau, R., 2008. Managing for conservation and recreation: the Ningaloo whale shark experience. J. Ecotour. 7 (2-3), 213-225.

Meka, J.M., McCormick, S.D., 2005. Physiological response of wild rainbow trout to angling: impact of angling duration, fish size, body condition, and temperature. Fish. Res. 72 (2), 311-322

Meletis, Z.A., Harrison, E.C., 2010. Tourists and turtles: searching for a balance in Tortuguero, Costa Rica. Conserv. Soc. 8 (1), 26.

Meyer, C.G., Dale, J.J., Papastamatiou, Y.P., Whitney, N.M., Holland, K.N., 2009. Seasonal cycles and long-term trends in abundance and species composition of sharks associated with cage diving ecotourism activities in Hawaii. Environ. Conserv. 36 (02), 104-111.

Miller, G., Rathouse, K., Scarles, C., Holmes, K., Tribe, J., 2010. Public understanding of sustainable tourism. Ann. Tour. Res. 37 (3), 627-645.

Moorhouse, T.P., Dahlsjö, C.A., Baker, S.E., D'Cruze, N.C., Macdonald, D.W., 2015. The customer isn't always right-conservation and animal welfare implications of the increasing demand for wildlife tourism. PLoS One 10 (10), e0138939.

Newsome, D., Lewis, A., Moncrieff, D., 2004. Impacts and risks associated with developing, but unsupervised, stingray tourism at Hamelin Bay, Western Australia. Int. J. Tour. Res. 6 (5), 305

Newsome, D., Dowling, R.K., Moore, S.A., 2005. Wildlife Tourism. Vol. 24. Channel View Publications.

Nugues, M.M., Roberts, C.M., 2003. Coral mortality and interaction with algae in relation to sedimentation. Coral Reefs 22 (4), 507-516.

O'Malley, M.P., Lee-Brooks, K., Medd, H.B., 2013. The global economic impact of manta ray watching tourism. PLoS One 8 (5), e65051.

Orams, M.B., 2002. Feeding wildlife as a tourism attraction: a review of issues and impacts. Tour. Manag. 23 (3), 281-293.

Orams, M.B., Hill, G.J., Baglioni, A.J., 1996. "Pushy" behavior in a wild dolphin feeding program at Tangalooma, Australia. Mar. Mamm. Sci. 12 (1), 107-117.

Orams, M.B., Hill, G.J., 1998. Controlling the ecotourist in a wild dolphin feeding program: is education the answer? J. Environ. Educ. 29 (3), 33-38

Parsons, E.C.M., 2012. The negative impacts of whale-watching. J. Mar. Biol. 2012

Pavez, G., Munoz, L., Barilari, F., Sepulveda, M., 2015. Variation in behavioral responses of the South American sea lion to tourism disturbance: implications for tourism management. Mar. Mamm.l Sci. 31, 427-439.

Pirotta, E., Lusseau, D., 2015. Managing the wildlife tourism commons. Ecol. Appl. 25, $729-741$.

Quiros, A.L., 2007. Tourist compliance to a code of conduct and the resulting effects on whale shark (Rhincodon typus) behaviour in Donsol, Philippines. Fish. Res. 84, 102-108.

Richards, K., O'Leary, B.C., Roberts, C.M., Ormond, R., Gore, M., Hawkins, J.P., 2015. Sharks and people: insight into the global practices of tourism operators and their attitudes to shark behaviour. Mar. Pollut. Bull. 91, 200-210.

Rosales, R.M.P., 2006. Estimating Appropriate Fines for Ship Grounding Violations in Tubbataha Reef National Marine Park. Conservation International Philippines, Quezon City.

Rosenberg, A., Bigford, T.E., Leathery, S., Hill, R.L., Bickers, K., 2000. Ecosystem approaches to fishery management through essential fish habitat. Bull. Mar. Sci. 66 (3), 535-542.

Rouphael, A.B., Hanafy, M., 2007. An alternative management framework to limit the impact of SCUBA divers on coral assemblages. J. Sustain. Tour. 15 (1), 91-103.

Saphier, A.D., Hoffmann, T.C., 2005. Forecasting models to quantify three anthropogenic stresses on coral reefs from marine recreation: anchor damage, diver contact and copper emission from antifouling paint. Mar. Pollut. Bull. 51 (5), 590-598. 
Schaffar, A., Madon, B., Garrigue, C., Constantine, R., 2009. Avoidance of whale watching boats by humpback whales in their main breeding ground in New Caledonia. IWC SC 61

Scheyvens, R., 1999. Ecotourism and the empowerment of local communities. Tour. Manag. 20 (2), 245-249.

Schleyer, M.H., Tomalin, B.J., 2000. Damage on South African coral reefs and an assessment of their sustainable diving capacity using a fisheries approach. Bull. Mar. Sci. 67 (3), 1025-1042.

Semeniuk, C.A.D., Speers-Roesch, B., Rothley, K.D., 2007. Using fatty-acid profile analysis as an ecologic indicator in the management of tourist impacts on marine wildlife: a case of stingray-feeding in the Caribbean. Environ. Manag. 40, 665-677.

Semeniuk, C.A.D., Bourgeon, S., Smith, S.L., Rothley, K.D., 2009. Hematological differences between stingrays at tourist and non-visited sites suggest physiological costs of wildlife tourism. Biol. Conserv. 142:1818-1829. http://dx.doi.org/10.1016/j.biocon.2009. 03.022 .

Shaalan, I.M., 2005. Sustainable tourism development in the Red Sea of Egypt threats and opportunities. J. Clean. Prod. 13 (2), 83-87.

Silva, L., 2015. How ecotourism works at the community-level: the case of whalewatching in the Azores. Curr. Issue Tour. 18, 196-211.

Sitar, A., May-Collado, L.J., Wright, A.J., Peters-Burton, E., Rockwood, L., Parsons, E.C.M., 2016. Boat operators in Boca del Toro, Panama display low levels of compliance with national whale-watching regulations. Mar. Policy 68, 221-228.

Smith, H., Samuels, A., Bradley, S., 2008. Reducing risky interactions between tourists and free-ranging dolphins (Tursiops sp.) in an artificial feeding program at Monkey Mia, Western Australia. Tour. Manag. 29 (5), 994-1001.

Smith, K., Scarr, M., Scarpaci, C., 2010. Grey nurse shark (Carcharias taurus) diving tourism: tourist compliance and shark behaviour at Fish Rock, Australia. Environ. Manag. 46 (5), 699-710.

Smith, K.R., Scarpaci, C., Scarr, M.J., Otway, N.M., 2014. Scuba diving tourism with critically endangered grey nurse sharks (Carcharias taurus) off eastern Australia: tourist demographics, shark behaviour and diver compliance. Tour. Manag. 45, 211-225.

Stafford-Bell, R., Scarr, M., Scarpaci, C., 2012. Behavioural responses of the Australian Fur Seal (Arctocephalus pusillus doriferus) to vessel traffic and presence of swimmers in Port Phillip Bay, Victoria, Australia. Aquat. Mamm. 38, 241-249.

Steckenreuter, A., Möller, L., Harcourt, R., 2012. How does Australia's largest dolphinwatching industry affect the behaviour of a small and resident population of IndoPacific bottlenose dolphins? J. Environ. Manag. 97, 14-21.

Suski, C.D., Killen, S.S., Cooke, S.J., Kieffer, J.D., Philipp, D.P., Tufts, B.L., 2004. Physiological significance of the weigh-in during live-release angling tournaments for largemouth bass. Trans. Am. Fish. Soc. 133 (6), 1291-1303.

Swarbrooke, J., 1999. Sustainable Tourism Management. Cabi.

The International Ecotourism Society, 2000. Ecotourism Statistical Fact Sheet. The International Ecotourism Society.

The Washington Post, 2013. Turtle Conservation Groups Reassess After Guardian is Killed in Costa Rican Beach. (Accessed online 4.11.2015: https://www.washingtonpost. $\mathrm{com} /$ national/health-science/turtle-conservation-groups-reassess-after-guardian-isshot-dead-on-costa-rican-beach/2013/06/04/bac9f8fe-cd45-11e2-8845d970ccb04497_story.html).

Tisdell, C., Wilson, C., 2002a. Economic, Educational and Conservation Benefits of Sea Turtle Based Ecotourism. Sustainable Tourism Cooperative Research Centre, Gold Coast.

Tisdell, C., Wilson, C., 2002b. Ecotourism for the survival of sea turtles and other wildlife. Biodivers. Conserv. 11 (9), 1521-1538.

Tisdell, C., Wilson, C., 2005a. Perceived impacts of ecotourism on environmental learning and conservation: turtle watching as a case study. Environ. Dev. Sustain. 7 (3), 291-302.

Tisdell, C.A., Wilson, C., 2005b. Does Tourism contribute to sea turtle conservation. Is the flagship status of turtles advantageous. pp. 145-167.

Troëng, S., Rankin, E., 2005. Long-term conservation efforts contribute to positive green turtle Chelonia mydas nesting trend at Tortuguero, Costa Rica. Biol. Conserv. 121 (1), 111-116.

Turner, A.M., Ruhl, N., 2007. Phosphorus loadings associated with a park tourist attraction: limnological consequences of feeding the fish. Environ. Manag. 39 (4), 526-533.

Uyarra, M.C., Côté, I.M., 2007. The quest for cryptic creatures: impacts of species-focused recreational diving on corals. Biol. Conserv. 136 (1), 77-84.

Van Waerebeek, K., Baker, A.N., Félix, F., Gedamke, J., Iñiguez, M., Sanino, G.P., ... Wang, Y. 2007. Vessel collisions with small cetaceans worldwide and with large whales in the Southern Hemisphere, an initial assessment. Lat. Am. J. Aquat. Mamm. 6 (1), 43-69.

Vignon, M., Sasal, P., Johnson, R.L., Galzin, R., 2010. Impact of shark-feeding tourism on surrounding fish populations off Moorea Island (French Polynesia). Mar. Freshw. Res. 61 (2), 163-169.

Wiley, D.N., Moller, J.C., PACE, R.M., Carlson, C., 2008. Effectiveness of voluntary conservation agreements: case study of endangered whales and commercial whale watching. Conserv. Biol. 22 (2), 450-457.

Wilkinson, C., 2008. Status of coral reefs of the world: 2008. Global Coral Reef Monitoring Network and Reef and Rainforest Research Centre, Townsville, Australia (296 pp.).

Wilkinson, C.R., Souter, D.N., 2008. Status of Caribbean Coral Reefs after Bleaching and Hurricanes in 2005. Global Coral Reef Monitoring Network.

Wilson, J., 2003. Planning policy issues for marine ecotourism. In: Garrod, B., Wilson, J.C (Eds.), Marine Ecotourism: Issues and Experiences. Channel View Publications, Clevedon, pp. 48-66.

Zeppel, $\mathrm{H}$, Muloin, S, 2007. Marine wild life tourism: education and conservation benefits. Proceedings of the 5th International Coastal and Marine Tourism Congress: Balancing Marine Tourism, Development and Sustainability (CMT2007). Auckland University of Technology, pp. 430-447.

Zeppel, H., 2009. Managing swim with wild dolphin tourism in Australia: guidelines, operator practices and research on tourism impacts. CAUTHE 2009. See Change: Tourism \& Hospitality in a Dynamic World, p. 676. 